\title{
A NOTE ON THE RAPID ASSAY
}

OF

\section{7-KETOGENIC STEROIDS IN URINE}

\author{
BY \\ G. GIBSON and J. K. NORYMBERSKI* \\ From the Rheumatism Research Unit, Nether Edge Hospital, Sheffield
}

(RECEIVED FOR PUBLICATION JANUARY 14, 1954)

The determination of urinary corticosteroids by their conversion to 17-ketosteroids (17-KS) on treatment of urine with sodium bismuthate has been recently reported (Norymberski, 1952; Norymberski, Stubbs, and West, 1953). The group of corticosteroids thus determined has been termed 17-ketogenic steroids (17-KGS). The interest in this method shown by colleagues from other laboratories prompts us to communicate a modification of the original procedure by which a considerable saving of time is achieved. The alteration of the technique consists in reacting the surplus bismuthate with sodium metabisulphite instead of removing it by centrifugation. This simple expedient dispenses with several operations and enables the oxidation, hydrolysis, and extraction of urine to be performed in one reaction vessel. As in the original method, the estimations are carried out with duplicate runs, but from each run only one sample is taken for the Zimmermann reaction. It is now possible for one person to perform in one day the combined estimation of 17-KS and 17-KGS on six urine specimens.

* Holder of an Empire Rheumatism Council Research Fellowship during the period in which this work was done.

\section{Experimental Procedure}

Estimation of 17-KS.-This is performed as previously described (Norymberski and others, 1953). The addition of acetic acid to urine before hydrolysis is now found to be unnecessary.

Estimation of "Total 17-KS" (17-KS+17-KGS).$2 \mathrm{ml}$. urine, $2 \mathrm{ml}$. glacial acetic acid, and $0.5 \mathrm{~g}$. sodium bismuthate are shaken for $\mathbf{3 0}$ minutes in a glass-stoppered centrifuge tube; care is taken to exclude direct daylight during this operation. $1 \mathrm{ml} .30$ per cent. sodium metabisulphite solution, $4 \mathrm{ml}$. water, and $3 \mathrm{ml}$. concentrated hydrochloric acid are added and the tube is placed for 10 minutes in a bath of boiling water. After cooling in cold water, $10 \mathrm{ml}$. ethylene dichloride are added, and the tube is shaken for 15 minutes and centrifuged. The top layer is removed by suction and the extract is shaken first with $2.5 \mathrm{ml}$ water for 2 minutes and then with $2.5 \mathrm{ml}$. $3 \mathrm{~N}$ sodium hydroxide solution for 5 minutes. After each wash the layers are separated as described above. The washed extract is filtered through a fluted paper and a sample of $5 \mathrm{ml}$. is taken for the colorimetric estimation. All other experimental details are as previously described (Norymberski and others, 1953).

\section{REFERENCES}

Norymberski, J. K. (1952). Nature (Lond.), 170, 1074 Stubbs, R. D., and West, H. F. (1953). Lancet, 1, 1276. 